\title{
Pengaruh kecerdasan adversitas dan prestasi kerja terhadap profesionalitas guru
}

\author{
Ermina Srihartini ${ }^{1}$, Rhini Fatmasari $^{\mathbf{1}^{*}}$, Tita Rosita $^{1}$ \\ ${ }^{1}$ Universitas Terbuka, Indonesia
}

\begin{tabular}{|c|c|}
\hline Article Info & ABSTRACT \\
\hline Article history: & This study aims to analyze the effect of adversity intelligence and work \\
\hline Received Oct $21^{\text {th }}, 2020$ & performance on the professionalism of teachers. This research is quantitative \\
\hline Revised Feb 04 ${ }^{\text {th }}, 2021$ & correlational research. The sample was determined using a random sampling \\
\hline Accepted Feb $15^{\text {th }}, 2021$ & technique of 135 people. The instrument used was a questionnaire of adversity \\
\hline & analysis tool was performed using the Structural Equation Modeling Method \\
\hline Keyword: & (SEM LISREL 8.30). The results showed that there was a significant effect of \\
\hline Kecerdasan Adversitas & adversity intelligence on teacher professionalism . There is a significant effect \\
\hline Prestasi Kerja & of adversity intelligence on work performance. There is a significant effect on \\
\hline Profesionalitas Guru & $\begin{array}{l}\text { work performance on teacher professionalism. The results of this study imply } \\
\text { that adversity intelligence and work performance are two factors that affect } \\
\text { teacher professionalism. }\end{array}$ \\
\hline
\end{tabular}

Corresponding Author:
Rhini Fatmasari
Universitas Terbuka
Email: riens@ecampus.ut.ac.id

\section{Pendahuluan}

Pendidikan merupakan faktor penting untuk kemajuan dan perkembangan suatu bangsa. Pendidikan yang berkualitas dapat menghasilkan sumber daya manusia yang ungul, produktif dan mampu menghadapi persaingan global, sehingga mendorong suatu bangsa menjadi negara maju pesat baik dalam bidang ilmu pengetahuan maupun teknologi.

Dengan demikian pendidikan merupakan faktor utama artinya pendidikan tidak akan pernah terlepas dari kehidupan manusia itu sendiri dan wajib dilaksanakan di manapun ia berada sepanajang masa. Sesuai dengan UU Sisdiknas No 20 Th 2003 pasal 1 ayat 1 dikatakan" Pendidikan adalah usaha sadar dan terencana untuk mewujudkan suasana belajar dan proses pembelajaran agar siswa secara aktif mengembangkan potensi dirinya untuk memiliki kekuatan spriritual keagamaan, pengendalian diri, kepribadian, akhlak mulia, dan keterampilan yang diperlukan dirinya, masyarakat, bangsa dan negara.

Berdasarkan data dari Sosial Progress Index 2016 sistem pendidikan Indonesia menempati urutan ke-40 dari 40 negara yang disurvey (Indra, 2016). Sedangkan menurut survey yang dilakukan oleh PISA 2015 (Programme for International Student Assessment) Indonesia berada di peringkat ke-62 dari 72 negara. Dari data tersebut menunjukkan rendahnya kualitas pendidikan di Indonesia (Tohir, 2016). Menurut pendapat Widodo (2015) "rendahnya kualitas pendidikan Indonesia disebabkan oleh banyak faktor diantaranya: 1) rendahnya sarana fisik, 2) rendahnya kualitas guru, 3) rendahnya kesejahteraan guru, 4) rendahnya prestasi siswa, 5) rendahnya kesempatan pemerataan pendidikan, 6) rendahnya relevansi pendidikan dengan kebutuhan, 7) mahalnya biaya pendidikan".

Rendahnya kualitas guru perlu mendapat perhatian serius karena guru merupakan faktor utama dalam pendidikan. Menurut pendapat Mangkunegara (2009) salah satu cara efektif meningkatkan kualitas guru adalah dengan peningkatan prestasi kerja guru. Guru yang memiliki prestasi kerja dan professionalitas tinggi memegang peranan penting dalam meningkatkan kualitas pendidikan di Indonesia. Menurut Hasibuan 
(2003) menyatakan bahwa prestasi kerja diartikan sebagai hasil kerja yang dicapai oleh seseorang dalam melaksanakan tugas-tugas yang dibebankan kepadanya yang didasarkan pada kecakapan, kesungguhan, dan waktu yang sudah ditetapkan. Hal senada disampaikan oleh Handoko (2014) bahwa prestasi kerja merupakan hasil kerja yang dicapai oleh tenaga kerja atau pegawai dalam melaksanakan tugas dan pekerjaan yang dibebankan kepadanya." Prestasi kerja meliputi aspek orientasi pelayanan, integritas, komitmen, disiplin, kerjasama, kepemimpinan. Untuk mengetahui prestasi kerja seseorang perlu adanya penilaian. Gaol (2014) menyampaikan pendapatnya bahwa faktor penilaian prestasi kerja seseorang didefinisikan sebagai suatu prosedur yang mencakup: 1) menetapkan standar kerja, 2) menilai prestasi kerja secara nyata dibandingkan dengan standar kerja yang ditetapkan, 3) memberikan umpan balik untuk memotivasi agar meningkatkan prestasi kerja menjadi lebih baik lagi.

Prestasi kerja guru merupakan tingkat pencapaian hasil kerja guru dalam melaksanakan tugas-tugas keguruannya dengan penuh tanggung jawab selama kurun waktu tertentu yang diakibatkan oleh berbagai faktor, baik faktor yang berasal dari luar (sekolah) maupun dari dalam diri guru sendiri sehingga mampu mengolah kemampuan kerjanya dengan usaha yang optimal untuk mencapai tujuan unit kerja/sekolah ( Sovia, 2016). Pendekatan hasil dikaitkan dengan pendidik atau guru adalah berfokus pada proses pengajaran yang dilakukan oleh guru. Hasil kerja seorang guru dapat dilihat dari, terjadinya peningkatan hasil belajar pada siswa dan keberhasilan guru dalam melaksanakan tugas lain yang berhubungan dengan pekerjaannya Prestasi kerja guru dapat diukur dengan perilaku kerja meliputi: 1) orientasi pelayanan, 2) integritas, 3) komitmen, 4) disiplin, 5) sikap, 6) kerjasama. Sedangkan menurut Heidjrahman dan Husnan (1990), faktorfaktor prestasi kerja yang perlu dinilai adalah sebagai berikut: 1) Kuantitas kerja, 2) Kualitas atau mutu kerja 3) Kehandalan bekerja. 4) Inisiatif, 5) Kerajinan 6) Sikap 7) Kehadiran.

Menurut Byar dan Rue (dalam Sutrisno, 2015) mengatakan bahwa ada dua faktor yang mempengaruhi prestasi kerja, yaitu faktor individu (usaha/effort, sifat/abilities, perilaku/ role and task perception) dan lingkungan (kondisi fisik, peralatan, waktu, materi, pendidikan, supervisi, desain organisasi, pelatihan dan keberuntungan). Pendapat senada disampaikan oleh Dale (dalam Mangkunegara, 2006) disebutkan bahwa faktor-faktor kinerja terdiri dari faktor internal (sifat-sifat seseorang) dan faktor eksternal. Salah satu faktor internal yang dapat mempengaruhi guru adalah kecerdasan adversitas.

Stoltz (2000) menyatakan bahwa kecerdasan adversitas adalah suatu kemampuan untuk mengubah hambatan menjadi peluang keberhasilan mencapai tujuan. Kecerdasan advesitas mempengaruhi produktivitas, kinerja, pengetahuan, kreativitas, pengambilan resiko, usia, motivasi, perbaikan, energi, vitalitas, stamina, kesehatan, dan kesuksesan seseorang. Kecerdasan adversitas akan memberitahukan empat hal, antara lain: 1) seberapa jauh seseorang mampu bertahan menghadapi kesulitan dan kemampuan untuk mengatasinya; 2) siapa yang mampu mengatasi kesulitan dan siapa yang akan hancur; 3) siapa yang akan melampaui harapan atas kinerja dan potensi mereka serta siapa yang akan gagal; 4) siapa yang akan menyerah dan siapa yang akan bertahan. Stoltz membagi kecerdasan adversity dalam 4 dimensi ,yaitu: 1) Kontrol (C=Control), 2) Asal usul dan pengakuan ( Origin dan Ownership ), 3) Jangkauan (Reach), 4) Daya tahan ( $\mathrm{E}=$ Endurance).Seseorang yang mempunyai kecerdasan adversitas yang tinggi akan produktif dan mempunyai kinerja yang lebih baik, memiliki motivasi tinggi dan mampu memegang kendali, akan merespon kesulitan secara konstruktif, berani mengambil resiko. Sejalan dengan penelitian Jason Satterfield dan Martin Seligman (dalam Stoltz, 2000) menemukan bahwa jika orang-orang merespon kesulitan secara optimis maka akan bersikap lebih agresif dan mengambil banyak resiko, masuk akal, dan yakin bahwa apa yang dilakukannya berfaedah. Dalam penelitiannya Dweck (dalam Stoltz, 2007) membuktikan bahwa orang yang optimis akan banyak belajar dari kesulitan dan berprestasi dalam kerja.

Sejalan dengan pendapat Niman (2004) dengan kecerdasan adversitas yang tinggi maka seseorang memiliki kemampuan untuk bertahan dalam kesulitan, akan membantu mengatasi masalah psikologis, lebih berani mengambil resiko dan peluang sehingga dapat meningkatkan prestasi kerja dan mampu meraih sukses. Dalam dunia pendidikan kecerdasan adversitas digunakan oleh para guru dalam mengembangkan daya tahan dan keuletan mereka dalam memberikan pelajaran bermakna, bertujuan dan sukses dalam melaksanakan berbagai tugasnya. Setiap guru memiliki kecerdasan yang berbeda-beda, dan dapat terus menerus dikembangkan. Kecerdasan adversitas dianggap sangat mendukung guru dalam menghadapi kesulitan yang sering muncul dalam melaksanakan tugas sebagai pengajar maupun pendidik di sekolah, dan akan berpengaruh terhadap prestasi kerja maupun profesionalitas guru (Stoltz, 2007). Kecerdasan adversitas menurut Hamdani (dalam Kusumawati, 2017) menyebutkan bahwa kecerdasan adversitas merupakan sesuatu potensi di mana dengan potensi tersebut seseorang dapat mengubah hambatan yang dihadapinya menjadi peluang, suksesnya pekerjaan dan hidup seseorang ditentukan oleh tingkat kecerdasan adversitasnya yang terus dapat dikembangkan seiring waktu. 
Sejalan dengan pendapat Taman, dkk (2013) dalam tinjauan kontribusinya terhadap kinerja profesional guru, kecerdasan adversitas berkontribusi terhadap profesionalitas guru karena guru dalam kaitannya menuju profesionalitas memerlukan daya juang yang tinggi dan juga strategi untuk memanfaatkan halangan menjadi sebuah peluang untuk maju. Kecerdasan adversitas yang dimiliki guru akan membantu dalam menghadapi kesulitan dan permasalahan ketika melaksanakan profesinya, memiliki motivasi tinggi, daya saing, produktivitas, berani menghadapi resiko, melakukan perbaikan dan pengembangan diri, ulet dalam bekerja, tahan terhadap tekanan dan memiliki ketekunan. Tingginya daya juang guru menggambarkan kemampuan guru menghadapi berbagai kesulitan dan hambatan untuk menjadikannya sebuah peluang sukses maka guru akan mempunyai pribadi yang tangguh, konsisten, prestasi kerja yang baik dan memiliki pendirian yang kuat sehingga akan fokus terhadap tugas sebagai guru yang memiliki profesionalitas tinggi.

Seperti yang dikutip dari Tribun pada peringatan Hari Guru Nasional (HGN) yang bertema "Meningkatkan Profesionalitas Guru Menuju Pendidikan Abad 21", Menteri Pendidikan dan Kebudayan (Mendikbud) Muhadjir Effendy menyampaikan (25/11/2018)"Ada tiga ciri guru profesional, antara lain: 1) Memenuhi kompetensi dan keahlian inti sebagai pendidik. Zaman terus berubah maka guru harus mampu menghadirkan pembelajaran abad 21 dengan cara menyiapkan peserta didik memiliki ketrampilan dalam berfikir kritis, kreatif, inovatif,komunikatif, dan mampu berkolaborasi. 2) Seorang guru yang profesional harus mampu membangun kesejawatan dan memupuk korsa guru. Bersama rekan sejawat, guru terus belajar, mengembangkan diri dan meningkatkan kecakapan untuk mengikuti laju perubahan zaman. 3) Seorang guru profesional hendaknya mampu merawat jiwa sosialnya". Menurut Priansa (2014) Profesionalitas mengacu pada sikap para anggota profesi terhadap profesinya serta derajat pengetahuan dan keahlian yang mereka miliki dalam rangka melakukan pekerjaannya. Sedangkan menurut Mulyasa (2006) Profesionalitas adalah kondisi, arah, nilai, tujuan, kualitas keahlian dan kewenangan yang berkaitan dengan mata pencaharian seseorang.

Setiap pekerjaan tidak terkecuali guru menuntut profesionalitas sesuai dengan bidangnya dan standar khusus sebagai tolok ukurnya. Seorang guru dikatakan profesioanal apabila dalam tugas mengajar mengacu pada norma-norma profesionalitas, mempunyai pengetahuan teoritik sesuai dengan mata pelajaran yang diajarnya, memiliki dasar-dasar mengajar, mempunyai kemampuan membimbing siswa, mempunyai kepribadian yang baik. Profesionalitas guru dapat diartikan sebagai sikap, kemampuan dan kewenangan guru dalam menjalankan profesi dengan kemampuan tinggi. Hal ini senada dengan pendapat Arifin (1995) bahwa profesionalitas adalah suatu pandangan terhadap suatu keahlian tertentu yang diperlukan dalam pekerjaan tertentu, yang diperoleh melalui pendidikan atau latihan khusus .

Menurut pendapat Rusman (2012) dijelaskan bahwa profesionalistas guru merupakan kondisi, arah, nilai, tujuan dan kualitas suatu keahlian dan kewenangan dalam bidang pendidikan dan pembelajaran yang berkaitan dengan pekerjaan seseorang yang menjadi mata pencaharian. Guru merupakan seorang profesional yang harus memiliki kompetensi keguruan yang memadai, serta berkemampuan dalam menerapkan konsep azas kerja dan tehnik dalam kerjanya, menguasai bahan ajar, mengelola program belajar mengajar, mengelola kelas, menilai prestasi kerja belajar siswa, menggunakan sumber dan media belajar dengan tepat, menerapkan bimbingan konseling belajar, mengelola interaksi belajar secara efisien dan efektif, menguasai landasan pendidikan dan mampu menafsir hasil penelitian yang bermanfaat untuk pengajaran secara maksimal. Sementara Fathorrahman (2017) menjelaskan bahwa profesionalitas guru menuntut guru untuk bekerja secara profesional. Guru profesional dituntut untuk memiliki kompetensi yaitu kompetensi paedagogik, kompetensi profesional, kompetensi sosial, kompetensi kepribadian. Lebih lanjut dikatakan semakin tinggi kompetensi tersebut maka semakin tinggi pula kinerja guru.

Sehubungan dengan penjelasan mengenai kecerdasan adversitas, prestasi kerja dan profesionalitas guru, maka penelitian ini bertujuan untuk mengetahui pengaruh kecerdasan adversitas terhadap profesionalitas guru, mengetahui pengaruh kecerdasan adversitas terhadap prestasi kerja, dan pengaruh prestasi kerja terhadap profesionalitas guru SDN Kecamatan Setu Kota Tangerang Selatan.

\section{Metode}

Penelitian dilaksanakan di SDN Kec.Setu Tangerang Selatan Banten, dengan pendekatan kuantitatif dan tehnik analisa SEM LISREL 8.30. Populasi dalam penelitian ini adalah 204 guru SDN Kecamatan Setu yang tersebar dalam 12 sekolah. Sampel diambil dari populasi terjangkau dengan tehnik simple random sampling. sebanyak 135 responden (menggunakan rumus Slovin). Pengumpulan data dalam penelitian menggunakan kuesioner yang disesuaikan dengan variabel yang akan diteliti (data primer) dan hasil UKG 
Guru Th 2015 (data sekunder) dengan model skala Likert. Variabel penelitian terdiri dari variabel eksogen yaitu kecerdasan adversitas (X1) dan variabel endogen prestasi kerja (X2) dan prifesionalitas guru (Y).

\section{Hasil Penelitian dan Pembahasan}

\section{Uji Kecocokan Model (Validitas \& Reliabilitas)}

Uji pengukuran dilakukan dengan cara menentukan validitas dan reliabilitas indikator-indikator dalam suatu konstruk.

Tabel 1.Validitas dan Reliabilitas Indikator

\begin{tabular}{|c|c|c|c|c|c|c|}
\hline Dimensi & SLF & Ei (Errorvar) & T-Hitung & $\mathbf{C R}$ & $\overline{\mathrm{VE}}$ & AVE \\
\hline \multicolumn{7}{|c|}{ X1 Kecerdasan Adversitas } \\
\hline $\mathrm{X} 1.1$ & 0.90 & 0.20 & 15.55 & 0.948 & 0.833 & 0,824 \\
\hline $\mathrm{X} 1.2$ & 0.87 & 0.25 & 13.09 & & & \\
\hline $\mathrm{X} 1.3$ & 0.91 & 0.18 & 14.84 & & & \\
\hline X1.4 & 0.95 & 0.10 & 16.61 & & & \\
\hline \multicolumn{7}{|c|}{ X2 Prestasi Kerja } \\
\hline $\mathrm{X} 2.1$ & 0.86 & 0.25 & 13.12 & 0.941 & 0.817 & 0,793 \\
\hline $\mathrm{X} 2.2$ & 0.87 & 0.24 & 14.32 & & & \\
\hline $\mathrm{X} 2.3$ & 0.91 & 0.17 & 15.69 & & & \\
\hline $\mathrm{X} 2.4$ & 0.92 & 0.14 & 16.13 & & & \\
\hline \multicolumn{7}{|c|}{ Y Profesionalitas } \\
\hline Y1 & 0.88 & 0.23 & 6.16 & 0.865 & 0.672 & 0,6178 \\
\hline Y2 & 0.71 & 0.49 & 7.38 & & & \\
\hline Y3 & 0.66 & 0.56 & 1.98 & & & \\
\hline Y4 & 0.87 & 0.24 & 1.97 & & & \\
\hline
\end{tabular}

Sumber: Hasil Olah Data (2017)

Pada tabel di atas, setiap indikator dari masing-masing variabel laten sudah memenuhi syarat karena loading factor-nya (SLF) $>0,50$ dan T-hitung $>$ T-Tabel $(1,97)$. Hasil perhitungan menunjukkan bahwa construct reliability variabel X1, X2 dan Y sudah memenuhi kriteria reliabel (god reliability). Nilai AVE untuk masing-masing variabel laten adalah $\geq 0,5$ menunjukkan data tersebut memiliki konvergensi yang memadai (adeguate convergen).(Gio, 2017)

Kecocokan Keseluruhan Model

Uji kecocokan model untuk menguji dapat atau tidaknya sebuah model dapat diterima. Nilai dari kriteria Good of Fit dapat dilihat pada Tabel dibawah ini.

Tabel 3. Hasil Kriteria Kesesuaian Model SEM

\begin{tabular}{lccc}
\hline \multicolumn{1}{c}{ Goodness-of-Fit } & Cut-off-Value & Hasil & Keterangan \\
\hline RMSEA (Root Mean Square Error of Approximation) & $\leq 0,08$ & 0,058 & Good Fit \\
GFI (Goodness of Fit) & $\geq 0,90$ & 0,97 & Good Fit \\
AGFI (Adjusted Goodness of Fit Index) & $\geq 0,90$ & 0,92 & Good Fit \\
CFI (Comparative Fit Index) & $\geq 0,90$ & 0.97 & Good Fit \\
\hline
\end{tabular}

Sumber: Data primer diolah, 2020

Berdasarkan nilai-nilai koefisien dari tabel di atas secara umum model yang diperoleh memiliki tingkat kecocokan data yang baik (good fit). 


\section{Persamaan Srtuktural}

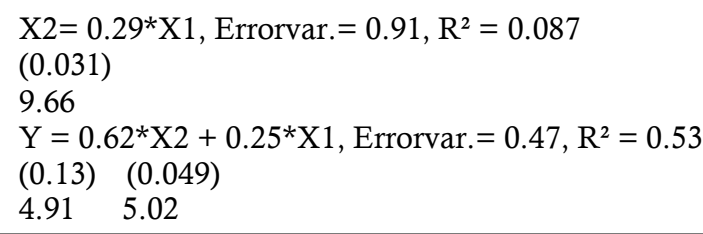

*Struktural Equations

\section{Prestasi Kerja $=0,29 *$ Kecerdasan Adversitas}

Kecerdasan adversitas berpengaruh positif terhadap prestasi kerja, dan t hitung menunjukkan signifikan yaitu 9,99 lebih besat dari t tabel 1,98

\section{Profesionalitas Guru = 0,62 Prestasi Kerja + 0,25 Kecerdasan Adversitas}

Prestasi kerja memberikan pengaruh lebih besar $(0,62)$ dibandingkan kecerdasan adversitas $(0,25)$ terhadap Profesionalitas Guru.

\section{Hasil Model Struktural}

Hasil model struktural output standardized loading factor dan output t hitung, signifikan sebesar $5 \%$ (default LISREL).

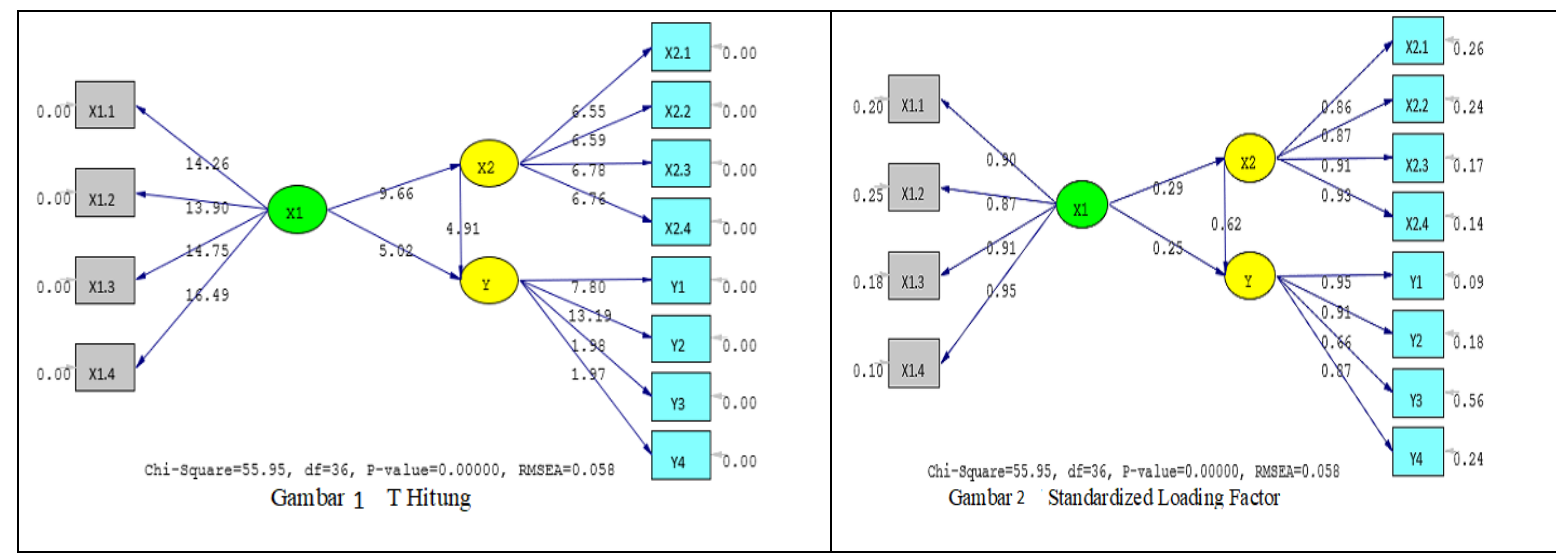

Hasil diperoleh, secara keseluruhan $t$ hitung variabel laten kecerdasan adversitas (X1) terhadap profesionalitas guru $(\mathrm{Y})$ adalah $\mathrm{t}$ hitung 5,02 $>\mathrm{t}$ tabel 1,98 maka kecerdasan adversitas berpengaruh signifikan terhadap profesionalitas guru. T hitung variabel laten kecerdasan adversitas (X1) terhadap prestasi kerja (X2) yaitu t hitung 9,66 > t tabel 1,98 maka kecerdasan adversitas berpengaruh signifikan terhadap prestasi kerja. Sedangkan t hitung variabel laten prestasi kerja (X2) terhadap profesionalitas guru $(\mathrm{Y})$ adalah $\mathrm{t}$ hitung 4,91> t tabel 1,98 maka prestasi kerja berpengaruh signifikan terhadap profesionalitas guru. Kecerdasan adversitas (X1) mempunyai pengaruh signifikan lebih besar terhadap profesionalitas guru dibanding dengan prestasi kerja.

Secara keseluruhan loading faktor variabel laten kecerdasan adversitas (X1) terhadap variabel laten profesionalitas guru $(\mathrm{Y})$ adalah 0,25 , variabel laten kecerdasan adversitas (X1) terhadap variabel laten prestasi kerja (X2) adalah 0,29 , dan variabel laten prestasi kerja (X2) terhadap variabel laten profesionalitas guru $(\mathrm{Y})$ adalah 0,62, menunjukkan hasil positif.Pengaruh prestasi kerja (X2) terhadap profesionalitas guru (Y) lebih besar dibandingkan pengaruh kecerdasan adversitas (X1) terhadap profesionalitas guru (Y).

\section{Pengaruh Kecerdasan Adversitas Terhadap Profesionalitas Guru}

Hasil analisa menunjukkan kecerdasan adversitas memiliki pengaruh untuk meningkatkan profesionalitas guru SDN di Kecamatan Setu. Nilai koefisien loading factor menunjukkan pengaruh kecerdasan adversitas terhadap profesionalitas guru positif, ini berarti jika terjadi peningkatan terhadap kecerdasan adversitas maka akan mampu meningkatkan profesionalitas guru.

Temuan ini mendukung penelitian yang dilakukan oleb Budiani dan Dantes (2014), menyatakan bahwa terdapat determinasi yang signifikan Adversity Ouotient (AQ) terhadap sikap profesionalisme guru SMP di Kec. Buleleng. Dalam penelitiannya ditemukan bahwa secara umum seseorang yang memiliki AQ yang 
tinggi berkolerasi positip terhadap sikap profesionalnya. Guru yang memiliki AQ yang tinggi dapat menyikapi kesulitan untuk menghadapi kehidupan yang penuh dengan tantangan, dan akan memberikan konstribusi positip terhadap sikap profesionalnya. Penelitian serupa dilakukan oleh Suherlan (2011) dinyatakan bahwa kecerdasan adversity mempunyai hubungan langsung dan hubungan tidak langsung dengan profesionalisme guru, semakin tinggi kecerdasan adversity, semakin tinggi pula profesionalisme guru, sedangkan secara total kecerdasan adversity mempunyai hubungan positif dengan profesionalisme guru. Salah satu usaha untuk meningkatkan profesionalisme guru dengan meningkatkan kecerdasan adversitynya.

Penelitian yang dilakukan oleh Oulette, Warner ( dalam Stoltz, 2007) menyatakan bahwa sifat tahan banting dan keuletan merupakan peramal-peramal bagi kinerja. Sifat tahan banting didasarkan pada suatu perasaan komitmen, tantangan, dan pengendalian. Orang yang memperlihatkan sifat tahan banting dan keuletan mengatasi kesulitan lebih baik daripada orang-orang yang tidak meiliki sifat tersebut. Dalam dunia pendidikan kecerdasan adversitas digunakan oleh para guru dalam mengembangkan daya tahan dan keuletan mereka dalam memberikan pelajaran yang mempunyai makna dan bertujuan. Dengan demikian kecerdasan adversitas merupakan salah satu faktor dominan yang mempengaruhi profesionalisme guru, salah satu upaya untuk meningkatkan profesionalisme guru dengan meningkatkan kecerdasan adversitas.

\section{Pengaruh Kecerdasan Adversitas Terhadap Prestasi Kerja}

Hasil analisa menunjukkan kecerdasan adversitas memiliki pengaruh untuk meningkatkan prestasi kerja guru SDN di Kecamatan Setu. Nilai koefisien loading factor menunjukkan pengaruh kecerdasan adversitas terhadap prestasi kerja positif, ini berarti jika terjadi peningkatan terhadap kecerdasan adversitas maka akan mampu meningkatkan prestasi kerja.

Penemuan ini mendukung hasil penelitian yang dilakukan oleh Dewi dan Sawitri (2015) membuktikan adanya hubungan positif yang signifikan antara kecerdasan adversity dan keterlibatan kerja. Semakin tinggi kecerdasan adversity maka semakin tinggi pula keterlibatan kerja seseorang, oleh karena itu perlunya ditingkatkatkan kecerdasan adversity melalui pelatihan dan pengembangan yang terus menerus. Penelitian senada juga dilakukan oleh Supardi (2015), dikatakan bahwa terdapat pengaruh positif dan signifikan Adversity Quotient terhadap prestasi belajar, prestasi belajar jika disertai Adversity Quotient maka prestasinya akan menjadi lebih baik. Menurut Puspita (2009) bahwa terdapat pengaruh kecerdasan adversity secara parsial terhadap kinerja baik, jika seseorang mempunyai kecerdasan adversity tinggi akan berpengaruh terhadap tingkat kinerjanya.

Berbeda dengan hasil penelitian Weno dan Matulessy (2015), bahwa terdapat hubungan negative antara adversity Quotient dengan kreativitas guru yang artinya semakin adversity quotiennya rendah maka semakin tinggi kreativitas seorang guru. Hal ini terjadi karena pemahaman Adversity Quotien pada setiap daerah berbeda begitu juga pemahaman terhadap kreativitas yang mana hal ini lebih kepada kognisi seorang guru. Sudah dapat dipastikan bahwa kinerja yang tinggi akan menghasilkan prestasi kerja yang tinggi pula. Penelitian ini menunjukan bahwa keberhasilan seseorang khususnya dalam dunia kerja tidak akan terlepas dari kecerdasan adversitas yang dimilikinya. Kecerdasan adversitas merupakan salah satu faktor dominan yang mempengaruhi prestasi kerja guru, dengan demokian salah satu upaya untuk meningkatkan prestasi kerja guru dengan meningkatkan kecerdasan adversitas.

\section{Pengaruh Prestasi Kerja Terhadap Profesionalitas Guru}

Hasil penelitian menunjukkan prestasi kerja memiliki pengaruh yang berarti untuk meningkatkan profesionalitas guru SDN di Kec.Setu. Nilai koefisien loading factor menunjukkan pengaruh prestasi kerja terhadap profesionalitas guru positif, ini berarti jika terjadi peningkatan terhadap prestasi kerja maka akan mampu meningkatkan profesionalitas guru.

Penemuan ini mendukung penelitian sebelumnya yang dilakukan oleh Razak (2016), menyatakan bahwa prestasi kerja dan kecerdasan adversity berpengaruh secara signifikan terhadap Profesionalitas Guru. Salah satu cara meningkatkan profesionalitas guru dengan meningkatkan kecerdasan adversita dan prestasi kerja secara terus menerus dengan berbagai pembinaan dan bimbingan yang berkelanjutan dan terus menerus. Hal ini sesuai dengan dengan hasil penelitian Stoltz (2007) yang menyatakan bahwa beberapa factor yang diperlukan untuk mengubah kegagalan menjadi suatu peluang yaitu daya saing, produktivitas, kreativitas, motivasi, mengambil resiko, ketekunan, belajar, merangkul perubahan, dan keuletan. Penelitian ini menunjukkan bahwa prestasi kerja merupakan salah satu factor yang dapat mempengaruhi profesionalitas guru, oleh karena itu sangatlah penting bagu guru untuk meningkatkan prestasi kerjanya secara maksimal dan terus menerus dengan berbagai cara, agar profesionalisme guru menjadi lebih baik. 


\section{Simpulan}

Dari hasil pengolahan data, maka dapat disimpulkan bahwa kecerdasan adversitas berpengaruh terhadap profesionalitas guru. Jika kecerdasan adversitas guru meningkat maka profesionalitas guru akan meningkat. Kecerdasan adversitas berpengaruh terhadap prestasi kerja. Ini berarti untuk meningkatkan prestasi kerja dapat dilakukan dengan meningkatkan kecerdasan adversitasnya. Prestasi kerja berpengaruh terhadap profesionalitas guru. Untuk meningkatkan profesionalitas guru dapat dilakukan dengan meningkatkan prestasi kerja. Prestasi kerja memberi pengaruh lebih tinggi terhadap profesionalitas guru dibanding kecerdasan adversitas. Dengan demikian guru harus menyadari pentingnya meningkatkan kecerdasan adversitasnya dengan berbagai cara dan bersama-sama dengan teman sejawat membenahi berbagai aspek untuk meningkatkan kecerdasan adversitas. Perlunya saling memotivasi untuk mengenali kekuatan-kekuatan sendiri dan menggunakan berbagai multi pendekatan terhadap guru agar mampu meraih kesuksesan dan prestasi kerja, sehingga profesionatitas guru disekolah tersebut terus menigkat. Memberikan apresiasi positif terhadap setiap keberhasilan guru, dan memotivasi guru agar selalu bangkit dari setiap kegagalan, terus selalu mencoba, dan memanfaatkan hambatan/kesulitan menjadi peluang kesuksesan. Lembaga yang berwenag dan Kepala Sekolah hendaknya terus menerus melakukan pembinaan terhadap prestasi kerja guru, dan terus berupaya peningkatan profesionalitas guru secara tepat sesuai kebutuhan dilapangan.

\section{Referensi}

Arifin. (1995). Kapita Selekta Pendidikan (Islam dan Umum. Bumi Aksara.

Arifin, M. (1991). Kapita Selekta Pendidikan Islam dan Umum. Bumi Aksara.

Budiani, I.A., Dantes, D. N. (2014). Determinasi Kecerdasan Emosional Dan Adversity Quotient (Aq) Terhadap Sikap Profesional Ditinjau Dari Status Profesi Guru Smp Di Kecamatan Buleleng Kabupaten Buleleng. E-Journal Program Pascasarjana Universitas Pendidikan Ganesha, 4(1), 1-13.

Dewi, N.K, Sawitri, R. D. (2015). Kecerdasan Adversitas Dan Keterlibatan Kerja Pada Karyawan Pt. Gandum Mas Kencana Kota Tangerang. Empati, 4(1), 123-129.

Dweck, C. S. (2017). Mindset, Mengerti Kekuatan Pola Pikir Untuk Perubahan Besar Dalam Hidup Anda, Parenting Business School Relationship, Temuan Psikologi Terbaru Untuk Meraih Kesuksesan (Cetakan 1). PT Bentara Aksara Cahaya.

Fathorrahman. (2017). Kompetensi Pedagogik, Profesional, Kepribadian, Dan Kompetensi Sosial Dosen. Akademika, 15(1), 1-6.

Gaol, M. L. (2014). A to Z Human Capital Manajemen Sumber Daya Manusia. Grasindo.

Gio, P. U. (2017). Panduan Mengolah Data dengan K-STAT (p. 136). https://doi.org/10.17605/OSF.IO/UE3YA

Handoko, T. H. (2012). Pengantar Manajeman Karangan T . Hani Handoko Bab 2. Faizal Nuzul Razak Hamid, S.E, 1(1), 30. https://www.academia.edu/12124668/BUKU_KARYA_T.HANI_HANDOKO

Hasibuan, M. S. (2003). Manajemen Sumber Daya Manusia (6th ed.). Bumi Aksara.

Heidjrachman, R., Husnan, S. (1990). Manajemen Personalia (Edisi 4). BPFE Yogyakarta.

Kusumawati, E. D. (2017). Pengaruh Adversity Quotient terhadap Regulasi Diri Siswa Kelas Khusus Olahraga ( KKO ) SMP Negeri 13 Yogyakarta. Jurnal Pendidikan Madrasah, 2(1), 121-141.

Mangkunegara, A. P. (2007). Manajemen Sumber Daya Manusia. PT Remaja Rosdakarya.

Mortell, A. (2000). Berani Menghadapi Kegagalan. Mitra Utama.

Mulyasa. (2017). Menjadi Guru Profesional Menciptakan Pembelajaran Kreatif dan Menyenangkan (ke 15). Rosda.

Nara Indra, P. A. (2016). Indonesia Huni Peringkat Buncit dalam Social Progress Index Baca selengkapnya di artikel "Indonesia Huni Peringkat Buncit dalam Social Progress Index", https://tirto.id/b7dC. Tirto.Id - Pendidikan. https://tirto.id/indonesia-huni-peringkat-buncit-dalam-social-progress-index-b7dC

Niman, S. (2017). Hubungan Konsep Diri Dengan Kecerdasan Adversitas. 40-44.

Pardede. (n.d.). Mendikbud Sampaikan 3 Ciri Guru Profesional dan Tantangan Abad 21 Artikel ini telah tayang di TribunKaltim.co dengan judul Mendikbud Sampaikan 3 Ciri Guru Profesional dan Tantangan Abad 21, https://kaltim.tribunnews.com/2018/11/25/mendikbud-sampaikan-3-ci. Tribun. https://kaltim.tribunnews.com/tag/hari-guru-nasional

Priansa, D. J. (2016). Kinerja dan Profesionalisme Guru. Alfabeta. https://doi.org/IOS3719.slims-2546

Puspita, W. A. (2009). Pengaruh Adversity Quotient Dan Motivasi Beprestasi Terhadap Kinerja Pendidik Paud Ditinjau Dari Kelompok Etnis. Jiv, 4(2), 175-188. https://doi.org/10.21009/jiv.0402.6

Putra, Y. M. P. (2015). UKG Dinilai Dorong Guru Lebih Profesional. Republika, 1. https://www.republika.co.id/berita/nyja5y284/ukg-dinilai-dorong-guru-lebih-profesional

Rachapoom, P., Tayraukham, S., Nuangchalerm, P. (2009). Causal Factors Influencing Adversity Quotient 
of Twelfth Grade and Third-Year Vocational Students Lalomwittaya School, Phusingh District, Sisaket Province , 33140 Thailand Department of Educational Research and Development , Faculty of Education, Mahas. Journal of Social Sciences, 5(4), 466-470.

Razak, E. A. (2016). Pengaruh Prestasi Kerja Dan Kecerdasan Adversity Terhadap Profesionalitas Guru Madrasah Ibtidaiyah Se-Kota Bogor Jawa Barat Institut Agama Islam Negeri Surakarta Tahun 1436 H / 2016 M [Institut Agama Islam Negeri Surakarta]. https://studylibid.com/doc/987077/pengaruh-prestasi-kerja-dankecerdasan-adversity-terhadap

Rusman. (2010). Model-Model Pembelajaran: Mengembangkan Profesionalisme Guru (Cetakan ke).

Sarwono, Y. (2010). Pengertian Dasar Structural Equation Modeling (SEM). Jurnal Ilmiah Manajemen Bisnis Ukrida, 10(3), 98528.

Sovia, I. (2020). Pengaruh Kemampuan Manajerial Kepala Sekolah Dan Iklim Kerja Terhadap Kerja Guru [Universitas Terbuka]. In Jurnal Pendidikan Tambusai. https://doi.org/10.31004/jptam.v4i3.866

Srinalia. (2015). Faktor-Faktor Penyebab Rendahnya Kinerja Guru dan Korelasinya Terhadap Pembinaan Siswa: Studi Kasus di SMAN 1 Darul Imarah Aceh Besar. Jurnal Ilmiah Didaktika, 15(2), 193-207. https://doi.org/10.22373/jid.v15i2.580

Stephen P Robbins. (2003). Perilaku Organisasi. Gramedia.

Stoltz. (2007). Adversitas Quotient: Mengubah Hambatan Menjadi Peluang (Hermaya T (ed.)). Gramedia.

Suherlan. (2011). Hubungan Aantara Kecerdasan Adversity Dan Motivasi Berprestasi Dengan Profesionalisme Guru Mts Negeri Se-Kabupaten Kuningan. IAIN SYEKH NURJATI CIREBON.

Supardi. (2013). Pengaruh adversity qoutient terhadap prestasi belajar matematika. Formatif: Jurnal Ilmiah Pendidikan MIPA, 3(1), 61-71. http://journal.lppmunindra.ac.id/index.php/Formatif/article/view/112/109

Sutrisno. (2015). Manajemen Sumber Daya Manusia. Kencana Prenada Media Group.

Taman S. .M Yudana, R. D. (2013). Kontribusi Motivasi Berprestasi, Disiplin Kerja, Dan Ketahanmalangan (Adversity Quotient) Terhadap Kinerja Profesional Guru Sma Negeri Di Kecamatan Karangasem Kabupaten Karangasem Bali. Jurnal Pendidikan, 4(1), 1-13. http://oldpasca.undiksha.ac.id/ejournal/index.php/jurnal_ap/article/view/1011

Tohir, M. (2016). Hasil PISA Indonesia tahun 2015 mengalami peningkatan. Tersedia Online: Https://Matematohir.Wordpress.Com/2016/12/08/Hasil-Pisa-Indonesiatahun-2015-Mengalami-Peningkatan/ [08 Desember 2016], 1(1), 1-2.

Utami, A. D. (2013). Pengaruh Adversity Quotient Terhadap Kinerja Perawat Dengan Motivasi Kerja Sebagai Variabel Mediasi (Studi di RSUD "Ngudi Waluyo" Wlingi). Jurnal Pendidikan, 11(1), 1-11.

UU SISDIKNAS, (2003). http://pendis.kemenag.go.id/file/dokumen/uuno20th2003ttgsisdiknas.pdf

Weno, J.H., Matulessy, A. (2015). Adversity Quotient, Komitmen Kerja dan Kreativitas Guru SD Kelas satu. Persona:Jurnal Psikologi Indonesia, 4(02), 162-174. https://doi.org/10.30996/persona.v4i02.558

Widodo, H. (2015). Potret Pendidikan Di Indonesia Dan Kesiapannya Dalam Menghadapi Masyarakat Ekonomi Asia (Mea). Cendekia: Journal of Education and Society, 13(2), 293-307. https://doi.org/10.21154/cendekia.v13i2.250 